\title{
DESAIN DAN OPTIMASI INJECTION MOLD SISTEM SLIDER PADA PRODUK PREFORM STICK T15
}

\author{
Lutfi Khoirul Miftakhul Ni'am¹, Cahyo Budiyantoro², Muhammad Budi Nur Rahman³ \\ 1,2,3Teknik Mesin, Universitas Muhammadiyah Yogyakarta \\ Jl. Lingkar Selatan Tamantirto, Kasihan, Bantul, DI Yogyakarta, Indonesia, 55183 \\ Telp: (0274) 387656 \\ E-mail: lutfikhoirul22@gmail.com
}

\begin{abstract}
The design of injection molding is the initial process to produce a large-scale product of plastic material which heated and injected into the mold. Design of the preform mold using the plastic material polyethylene terephthalate with the construction of the slider, so that the products which was made have undercut and can't be made in the core section and cavity. The purpose of this design is to design the slider on the product preform. The software which used for this design using CATIA V5R19 and simulation software production using Autodesk Moldflow Insight 2016. The step on designing a unit injection mold in the preform includes several steps. The first step is identify the product, the calculation of the cooling and input the data calculation result to an moldflow. The second step is design construction slider and determine the mold material as well as calculating the construction mold. The third step is pour the results of the design in figure 2D. Based on the analysis results from moldflow obtained cooling optimal.i.e. the type of cooling series type 2, and if can be concluded construction of the mold said to be safe if the stress, the style and the determination of material which occurs under the stress and style of permit.
\end{abstract}

Keywords: Injection molding, slider, undercut, cooling.

\section{PENDAHULUAN}

Perkembangan industri saat ini kemasan merupakan produk yang mempunyai undercut merupakan suatu kebutuhan bagi industri atau tonjolan pada sisi ulir maka pada cetakan makanan. Plastik dikenal sebagai suatu bahan harus didukung oleh kontruksi slider mold. serbaguna dan ekonomis yang banyak Sistem slider merupakan bagian yang tidak digunakan berbagai macam produk kemasan. dapat dibentuk dengan hanya core dan cavity. Sifat material plastik yang harus dimiliki oleh Berbagai bentuk produk yang dibuat suatu bahan pengemas diantaranya adalah ditentukan di sebuah mold [2].

tahan terhadap cuaca, dan bahan kimia.

Pembuatan sebuah cetakan merupakan

Proses pengolahan material plastik ini proses awal untuk memproduksi suatu produk menggunakan metode injection molding, yaitu dengan skala besar. Kualitas suatu produk metode dari pembentukan material ditentukan di langkah pembuatan cetakan termoplastik dimana material yang meleleh injeksi [3]. Maka perancangan mold harus akibat panas dan gesekan didalam barrel dilakukan dengan baik sebelum masuk ke diinjeksikan kedalam sebuah cetakan (mold), langkah selanjutnya. Desain cetakan preform kemudian didinginkan oleh air atau oil Stick T15, ada beberapa hal yang menjadi sehingga produk mengeras [1].

Studi perancangan yang kali ini digunakan adalah preform Stick T15 untuk produk plastik preform atau bentuk awal dari kemasan makanan (toples). Material plastik yang digunakan untuk pembuatan preform adalah polyethylene terephthalate (PET) yang mempunyai sifat kekuatan (strength) tinggi, kaku (stiffness), dimensinya stabil, tahan bahan kimia, dan panas. Produk preform ini perhatian khusus untuk membuat produk yang menghasilkan undercut yaitu, sistem slider, ejection system, dan cooling, dan bagaimana sistem slider mold bekerja pada produk preform stick T15 [4]. Mengatasi hal tersebut maka dibutuhkan perancangan sistem slider.

Tujuan perancangan cetakan injeksi adalah untuk mendesain konstruksi slider mold pada produk preform stick T15, serta mengamati hasil simulasi dari sistem cooling yang 
dirancang pada produk preform stick $\mathrm{T} 15$, dan melakukan perhitungan pada sistem slider, cooling, dan konstruksi mold [5].

\section{METODOLOGI PERANCANGAN}

Metode perancangan terdapat beberapa tahapan dalam perancangan cetakan (mold slider) injeksi yaitu, mengidentifikasi produk, melakukan analisa dan perhitungan pada cooling, mendesain setiap konstruksi mold, menentukan material, dan melakukan perhitungan pada konstruksi slider mold.

\section{Bahan Perancangan}

Produk yang dirancang adalah preform stick T15 dengan mengambil sampel yang sudah ada. Dimensi dan bentuk berbeda, produk hanya sebagai acuan. Pada gambar 1 , menunjukkan sampel produk preform stick T15.

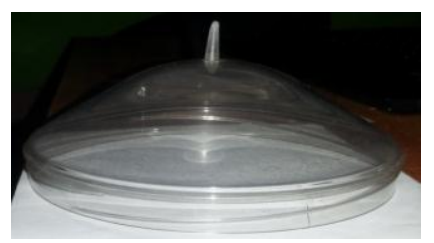

Gambar 1. Sampel produk preform Stick T15

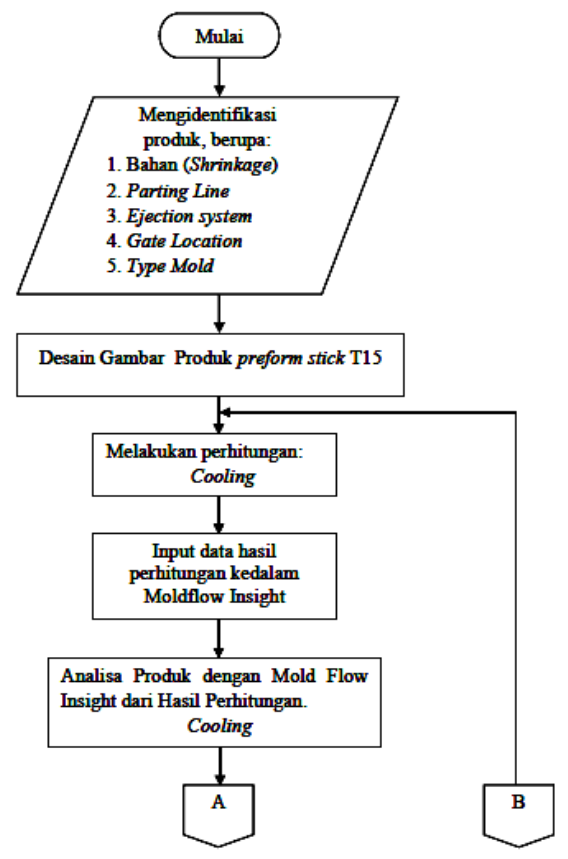

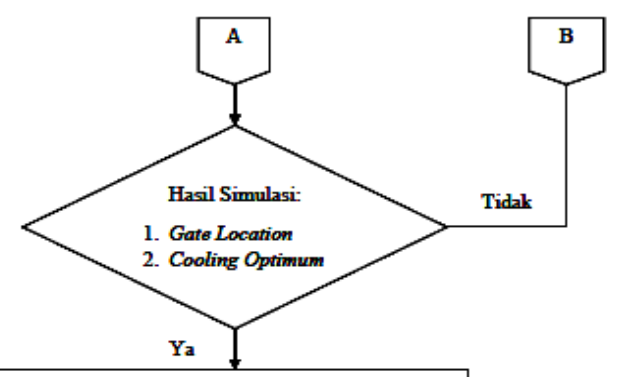

Desain Konstruksi Sider Mold dengan

Penentuan Mold Material

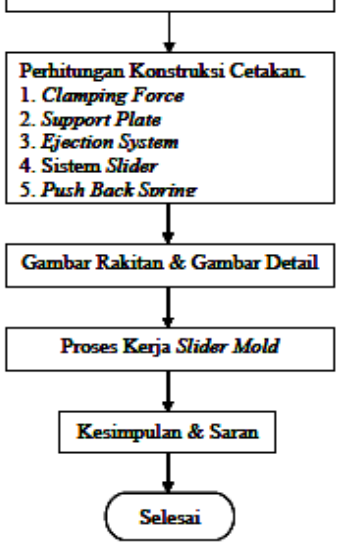

Gambar 2. Diagram alir perancangan

\section{Alat Perancangan}

Alat yang digunakan dalam perancangan preform stick T15 dan konstruksi slider mold, menggunkan beberapa alat sebagai berikut:

a. Laptop

Tabel. 1. Spesifikasi Lenovo B40

\begin{tabular}{ll}
\hline Operation System & Windows 8.1 \\
\hline Processor & $\begin{array}{l}\text { AMD Radeon } \\
\text { Graphics }\end{array}$ \\
\hline CPU & Core i3 - 4010U 1.70 \\
& Ghz \\
\hline Installed Memory & $4.00 \mathrm{~GB}$ \\
(RAM) & \\
\hline System Type & $\begin{array}{l}\text { 64-bit Operating } \\
\text { System }\end{array}$ \\
\hline
\end{tabular}

b. Software perancangan dan simulasi produk Software yang digunakan untuk perancangan menggunakan CATIA V5R19 dan software simulasi produk menggunakan Autodesk Moldflow Insight 2016.

c. Jangka sorong (vernier caliper).

d. Kalkulator. 


\section{Identifikasi Produk}

a. Bahan.

Sampel produk preform stick T15 dapat di identifikasi material yang digunakan melalui fungsi dari produk atau jenis produk preform yang sudah masuk kedalam spesifikasi material bahan. Kemudian dapat diketahui dimensi sampel produk di dalam cetakan dengan cara mencari nilai shrinkage pada material bahan yang digunakan.

b. Parting Line.

Melalui sampel produk preform stick T15 dapat di identifikasi letak parting line dengan melihat tanda undercut pada produk preform berupa ulir. Bagian yang terpisah oleh parting line disebut core dan cavity.

c. Ejection System.

Tanda ejector biasanya terlihat pada produk-produk tertentu, tetapi dari sampel produk preform tanda ejector tidak terlihat. Maka dari itu diperlukan untuk menentukan jenis ejector yang akan digunakan.

d. Lokasi Gate.

Letak lokasi gate dapat dilihat dari gate yang membekas pada produk preform. kemudian tipe gate yang digunakan juga dapat diketahui.

e. Type Mold.

Penggunaan jenis cetakan dapat ditentukan dari bentuk produk seperti pada sampel produk preform.

\section{HASIL PERANCANGAN SLIDER MOLD}

Syarat dari perancangan mold meliputi identifikasi produk, analisa cooling, langkah urutan desain, penentuan mold material, hasil perhitungan konstruksi mold, dan proses kerja slider mold.

a. Data Produk

Tabel. 2. Data Produk

\begin{tabular}{lc}
\hline \multicolumn{2}{c}{ Data Produk } \\
\hline Nama & Preform Stick T15 \\
\hline Warna & Putih (Transparan) \\
\hline Material & $\begin{array}{l}\text { Polyethylene } \\
\text { terephthalate }\end{array}$ \\
\hline Shrinkage & $3 \%$ \\
\hline Dimensi produk & $140 \mathrm{~mm} \times 63,5 \mathrm{~mm}$ \\
\hline Tebal produk & $2 \mathrm{~mm}$ \\
\hline Berat Produk & 6 gram \\
\hline
\end{tabular}

\section{b. Parting Line}

Penentuan parting line juga memperhatikan estetika atau keindahan produk.

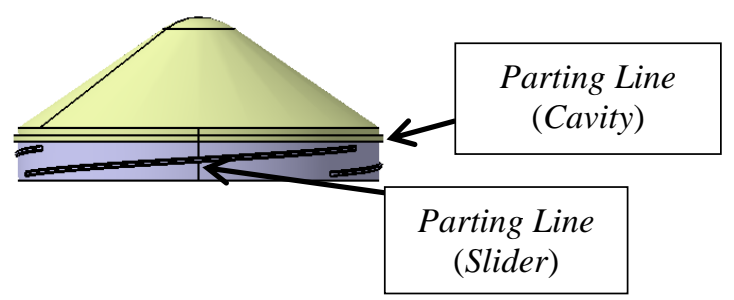

Gambar 3. Parting Line

Kasus preform di atas parting line ini dibagi menjadi dua bagian yakni pada cavity dan slider, karena untuk core sendiri dibuat insert maka yang bisa ditentukan pada parting line diatas hanya cavity dan slider.

\section{c. Ejection System}

Tanda ejector biasanya terlihat pada produk-produk tertentu atau biasanya tanda ejector berbentuk lingkaran, tetapi dari sampel produk preform tanda ejector tidak terlihat jelas.

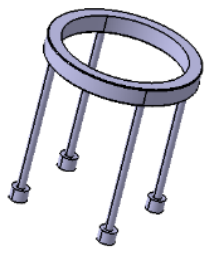

Gambar 4. Ejection system

Gambar 4, merupakan type ejector untuk mengeluarkan sebuah produk di dalam cetakan, ejector akan bekerja mendorong produk dari sisi diameter produk. Maka type ejector stripper plate inilah yang sesuai untuk produk semacam preform.

\section{Hasil Analisa Produk Preform Stick T15 dengan Moldflow Insight}

\section{a. Hasil Analisa Gate}

Gambar 5, merupakan letak lokasi gate yang disarankan dari analisa yang ditunjukan pada warna biru sangat baik digunakan untuk menempatkan gate karena menghasilkan aliran yang radial terlihat letaknya yang simetris sehingga distribusi material bagus. 


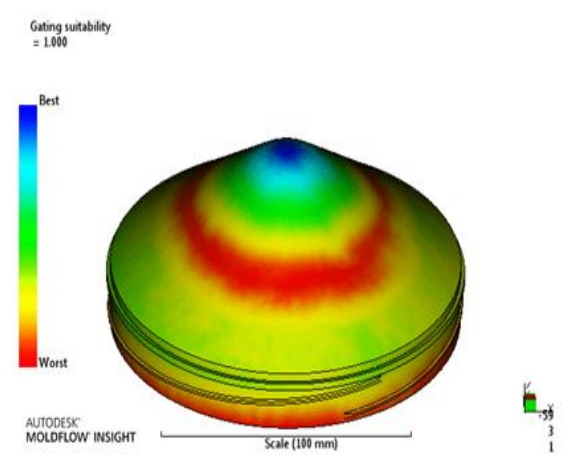

Gambar 5. Gate location

b. Hasil Analisa Fill Time

Hasil analisa menunjukkan waktu atau nilai maksimum yang dibutuhkan untuk memenuhi produk preform stick T15 adalah 1,634 s.

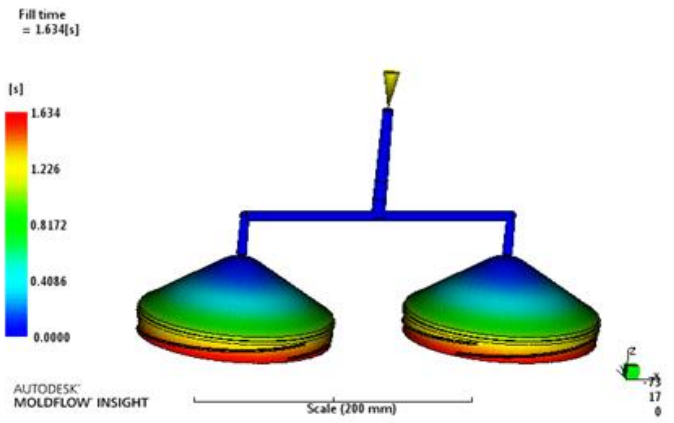

Gambar 6. Fill Time

\section{Hasil Analisa Cooling System}

\section{a. Circuit Coolant Temperature}

Hasil analisis suhu pendingin di sirkuit yang ditunjukkan pada gambar 7 dan 8, perbedaan suhu antara saluran masuk dan keluar idealnya harus kurang dari $2^{\circ} \mathrm{C}$. Jika selisihnya lebih dari $2^{\circ} \mathrm{C}$ maka akan menyebabkan medan suhu dan deformasi yang tidak rata.

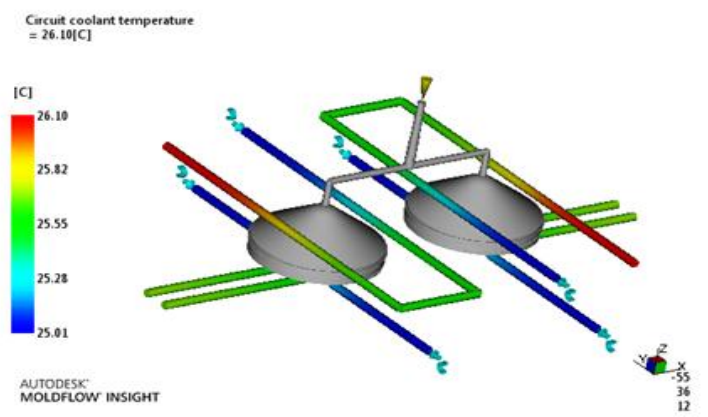

Gambar 7. Circuit Coolant type 1

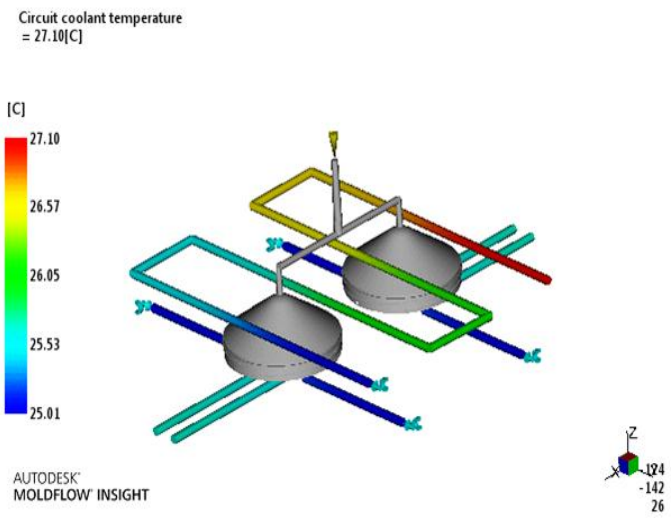

Gambar 8. Circuit Coolant type 2

Analisa di atas menunjukkan hasil temperatur circuit coolant type 1 yaitu $1,11^{\circ} \mathrm{C}$, sedangkan analisa pada hasil temperatur circuit coolant type 2 yaitu $2,11^{\circ} \mathrm{C}$.

b. Circuit metal temperature

Analisa Circuit metal temperature menjelaskan temperatur tertinggi di dalam cooling ketika melakukan proses pendinginan.

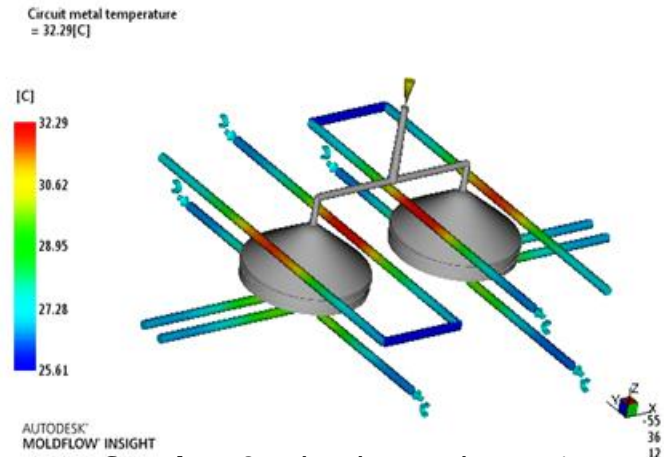

Gambar 9. circuit metal type 1

Pada gambar 9. circuit metal type 1 didapatkan temperatur tertinggi ditunjukkan pada channel berwarna merah yaitu $32,29^{\circ} \mathrm{C}$. Sedangkan pada gambar 10 , circuit metal type 2 temperatur channelnya lebih tinggi yaitu $32,88^{\circ} \mathrm{C}$. Temperatur yang baik digunakan dalam analisa circuit metal temperature adalah yang memiliki temperatur rendah untuk menjaga fluida pendingin tidak cepat mengalami kanaikan suhu. 


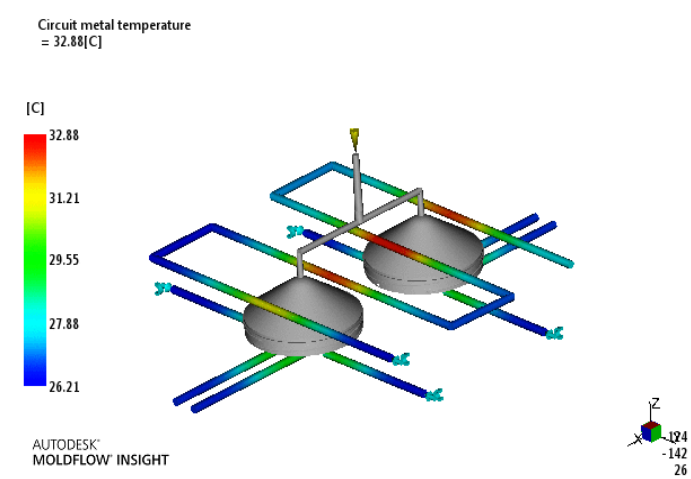

Gambar 10. circuit metal type 2

c. Time to reach ejection temperature, part Waktu yang dibutuhkan untuk mencapai temperatur ejeksi pada cooling seri dan baffle type 1 yang ditunjukan pada gambar 11 membutuhkan waktu 10,34 s untuk mendinginkan produk sebelum proses ejeksi. Sedangkan pada cooling seri dan baffle type 2 yang ditunjukkan pada gambar 12 membutuhkan waktu 10,26 s. Semakin cepat waktu pendinginan semakin memperpendek waktu produksi, jadi memberikan keuntungan lebih di dunia industri.
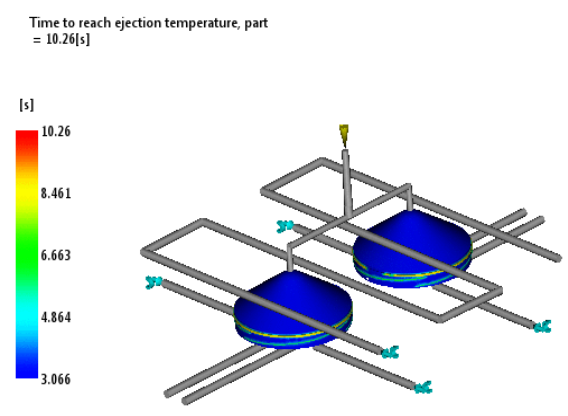

AUTODESK:
MOLDFLW INSIGHT

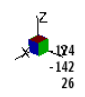

Gambar 11. Time to reach ejection type 1

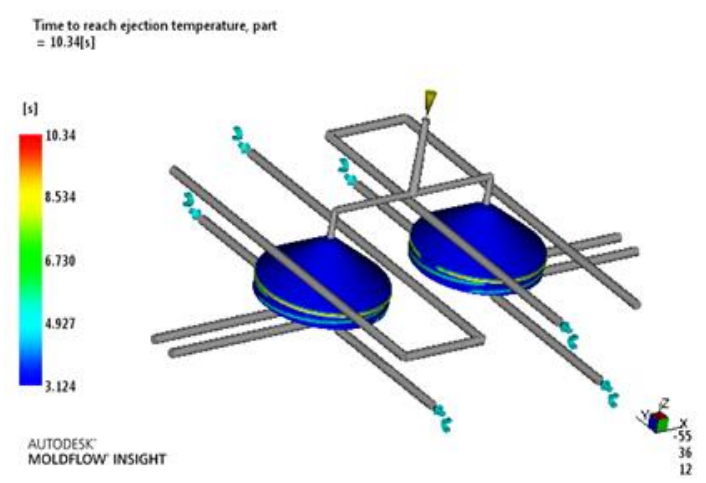

Gambar 12. Time to reach ejection type 2

\section{d. Circuit heat removal efficiency}

Circuit heat removal efficiency merupakan efisiensi penyerapan panas oleh cooling terhadap produk preform Stick T15. Gambar 13 menunjukkan efisiensi penyerapan panas dari angka 0,50 - 0,75 dengan keefektifan perpindahan panas, begitupun juga pada gambar 14 dari angka 0,5284 - 0,7642 menunjukkan keefektifan efisiensi penyerapan panas.

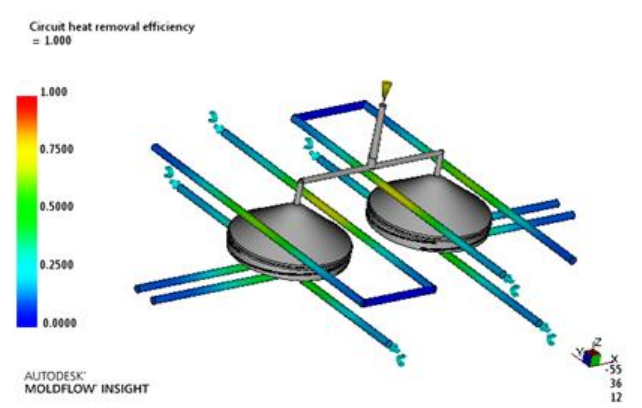

Gambar 13. Circuit heat removal type 1

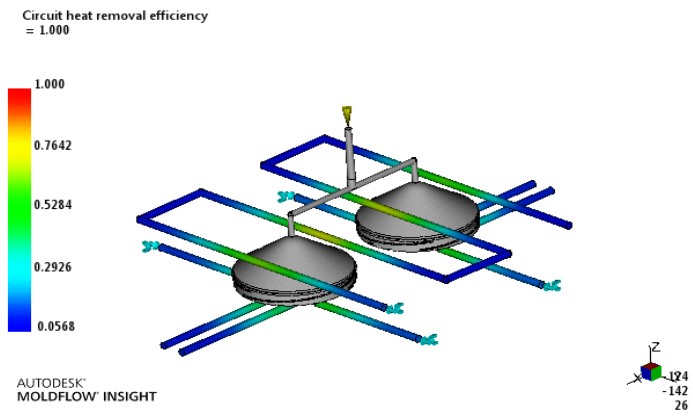

Gambar 14. Circuit heat removal type 2

e. Deflection, all effects:Deflection

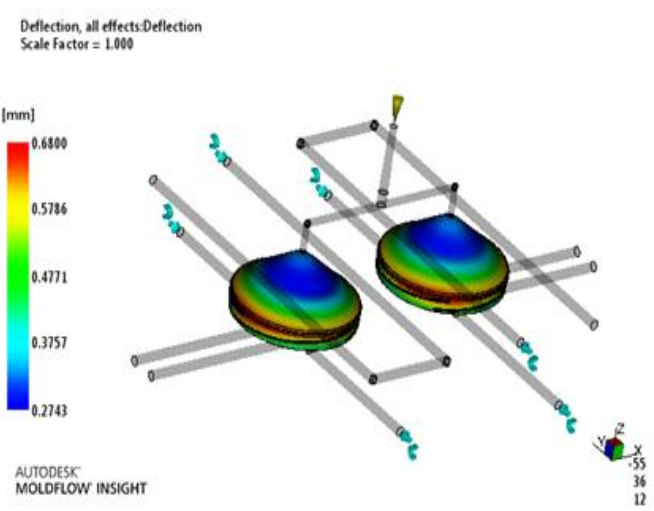

Gambar 15. Deflection, all effects type 1 


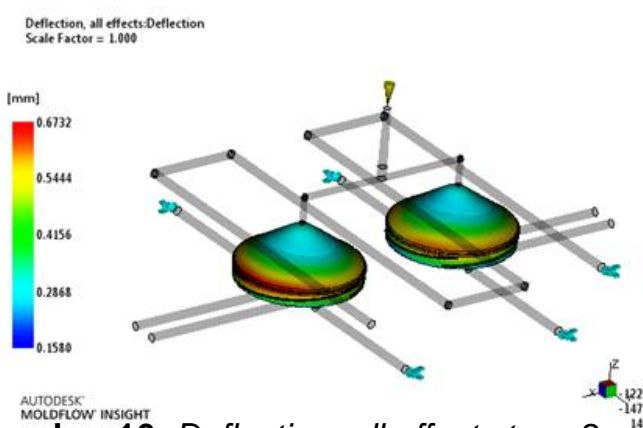

Gambar 16. Deflection, all effects type 2

Tabel 3 dibawah ini adalah hasil nilai perbandingan cooling dan hasil rekomendasi cooling.

Tabel 3. Hasil nilai perbandingan cooling

\begin{tabular}{lcc}
\hline \multicolumn{1}{c}{$\begin{array}{c}\text { Analisa } \\
\text { Cooling }\end{array}$} & \multicolumn{2}{c}{ Type Cooling } \\
\hline \multicolumn{1}{c}{ Type 1 } & Type 2 \\
\hline $\begin{array}{l}\text { Circuit coolant } \\
\text { temperature. }\end{array}$ & $1,11^{\circ} \mathrm{C}$ & $2,11^{\circ} \mathrm{C}$ \\
\hline $\begin{array}{l}\text { Circuit metal } \\
\text { temperature. }\end{array}$ & $32,29^{\circ} \mathrm{C}$ & $32,88^{\circ} \mathrm{C}$ \\
\hline $\begin{array}{l}\text { Time to reach } \\
\text { ejection } \\
\text { temperature, part. }\end{array}$ & $10,34 \mathrm{~s}$ & $10,26 \mathrm{~s}$ \\
\hline $\begin{array}{l}\text { Circuit heat } \\
\text { removal } \\
\text { efficiency. }\end{array}$ & $0,50-$ & 0,5284 \\
\hline $\begin{array}{l}\text { Deflection all } \\
\text { effects: } \\
\text { Deflection. }\end{array}$ & 0,75 & 0,7642 \\
\hline
\end{tabular}

Berdasarkan hasil analisa dan perbandingan cooling di atas, maka di pilihlah cooling yang optimum dan terbaik adalah Cooling seri dan baffle type 2 merupakan pendingin yang direkomendasikan.

\section{Hasil Perancangan Mold}

Data hasil analisa dari moldflow insight di dapatkan cooling yang optimal yaitu jenis cooling seri dan baffle type 2. Kemudian data hasil analisa direkomendasikan sebagai landasan untuk melakukan perancangan konstruksi slider mold.

\section{Langkah urutan desain}

Sebelum mendesain komponen plat yang pertama kali dilakukan adalah penentuan moldbase pada produk preform yang digunakan adalah standar moldbase Futaba D.E series 4060 . Sekaligus penentuan material penting dilakukan untuk menghitung beberapa konstruksi yang menerima perlakuan yang berbeda sesuai sistem kerja tiap konstruksi pada mold (Jones, 2008).

\section{D. $E_{\text {sories }} 4060$}

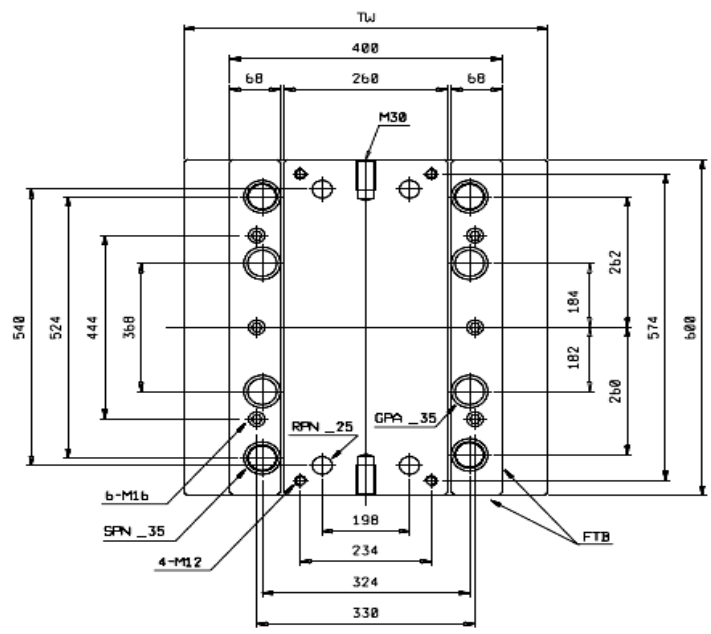

Gambar 17. Standar moldbase Futaba D.E series 4060

Dibawah ini merupakan urutan desain.

1. Cavity Plate.

2. Core Plate.

3. Slide Core (Slider).

4. Insert Core.

5. Locking Block.

6. Support Plate.

7. Distance Block.

8. Ejector Plate.

9. Ejector Back Plate.

10. Bottom Clamping Plate.

11. Manifold Block.

12. Top Clamping Plate.

13. Standar komponen.

\section{Hasil Desain Mold}

Hasil desain mold ditunjukkan pada gambar 18. 


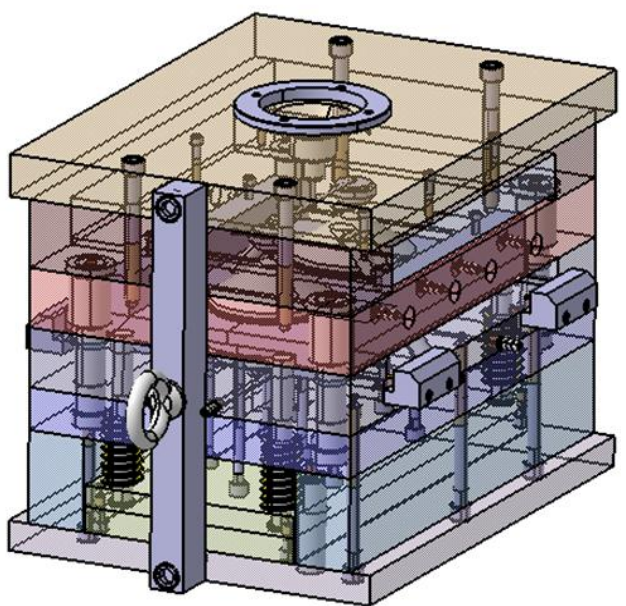

Gambar 18. Hasil perancangan slider mold

\section{Penentuan Mold Material}

Penentuan material penting dilakukan untuk menghitung beberapa konstruksi yang menerima perlakuan yang berbeda sesuai sistem kerja tiap konstruksi pada mold. Adapun dasar penentuan material plat dan komponen mold ini mengacu pada mold basic design textbook IMDIA [6] dengan rujukan langsung dari standar Futaba dan Misumi sebagai produsen pembuatan komponen mold.

Tabel 4. Penentuan Mold Material

\begin{tabular}{clc}
\hline No & \multicolumn{1}{c}{ Deskripsi } & Material \\
\hline 1. & Cavity Plate & S50C \\
2. & Core Plate & S50C \\
3. Support Plate & SS400 \\
4. Ejector Plate & SS400 \\
5. Ejector Back plate & SS400 \\
6. Distance block & SS400 \\
7. Manifold plate & S45C \\
8. Top clamping plate & S45C \\
9. Return Pin_M_RPN & SUJ2 \\
10. Bottom clamping plate & SS400 \\
11. Locating Ring_E1365 & S45C \\
12. Slide core & SKD61 \\
13. Insert core & SKD11 \\
14. AnglePin_Z01 & SUJ2 \\
\hline
\end{tabular}

\begin{tabular}{ll}
\hline 15. Locking block & SKS3 \\
16. Manifold block & S45C \\
17. Nozzle gate bushing & S45C \\
18. Sprue Bushing_AG & S45C \\
19. Core stop block & S45C \\
20. Spring_SWR & S45C \\
21. Knock_Out_M_BSA & SKD61 \\
22. Bushing_M-GBA & SUJ2 \\
23. LeaderPin_M-SPN & SUJ2 \\
24. Cap Screw_M & SCM 435 \\
25. Connector_Plug & Brass (C3604) \\
26. Ball plunger & SUJ2 \\
27. Stripper plate ejection & SKH51 \\
28. Stripper ring & SKH51 \\
29. Baffle_BFPT & SCM45 \\
30. Eye Bolt & SS400 \\
\hline
\end{tabular}

\section{Hasil Perhitungan Konstruksi}

a. Hasil Perhitungan Clamping Force

Perhitungan ini bertujuan untuk menentukan mesin injeksi yang akan digunakan, didapatkan pada analisa moldflow yaitu 125 Ton. Sehingga dipilih mesin yang memiliki kapasitas tonase $20 \%$ diatas clamping force mold preform stick T15 yaitu 150 Ton. Perancang memilih mesin injeksi yang memiliki 160 Ton gaya clamping untuk menahan gaya saat proses pengisian dan pendinginan(Gambar 19).

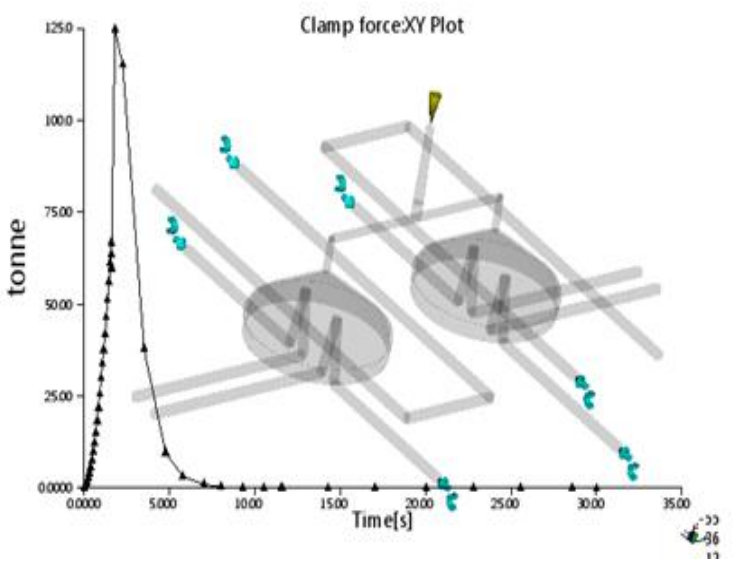

Gambar 19. Hasil perhitungan clamping force

b. Hasil Perhitungan Kekuatan ejector

Perhitungan ini bertujuan untuk menentukan beban kritis yang dapat diterima oleh stripper plate, dimana beban buckling 
(beban stripper plate) harus dibandingkan dengan gaya yang diperlukan untuk mengeluarkan produk, dengan keliling cavity $879 \mathrm{~mm}$ dan tebal produk $2 \mathrm{~mm}$. Material stripper plate menggunkan SKH51 dengan diameter stripper plate ejection $13 \mathrm{~mm}$ dan panjang $150 \mathrm{~mm}$, adapun hasil dari penentuan beban kritis yang diterima oleh stripper plate dimana ejecting load < collapsing load dan gaya cavity terhadap permukaan < collapsing load yaitu 350,649 $\mathrm{N}<94311,93 \mathrm{~N}$ dan 3926,9 $\mathrm{N}<94311,93 \mathrm{~N}$.

c. Hasil Perhitungan Push Back Spring

Push back spring berfungsi untuk mengembalikan ejector plate, dan ejector pin pada posisinya semula. Gaya minimal yang dibutuhkan pegas sama dengan gaya yang diakibatkan adanya gaya tekan akibat berat ejector plate, hasil yang diperoleh gaya persatu pegas yaitu sebesar $75,17 \mathrm{~N}$, kemudian menentukan spring berdasarkan 3 jenis spring pada katalog Misumi, yakni SWR 31-80, SWS 31-80, dan SWN 31-80. Tabel 5 menunjukkan hasil perhitungan spring.

Berdasarkan hasil perhitungan, maka dilakukan pemilihan spring yang paling sesuai. Pertimbangan dalam pemilihan spring adalah beban awal dan beban akhir tidak terlalu keras, selain itu mengusahakan supaya spring tidak longgar (oblag). Berikut ini dijelaskan pemilihan spring.

Tabel 5. Hasil Perhitungan Spring

\begin{tabular}{cccc}
\hline Deskripsi & $\begin{array}{r}\text { SWR } \\
\mathbf{3 1 - 8 0}\end{array}$ & $\begin{array}{c}\text { SWS } \\
\mathbf{3 1 - 8 0}\end{array}$ & $\begin{array}{c}\text { SWN } \\
\mathbf{3 1 - 8 0}\end{array}$ \\
\hline $\begin{array}{c}\text { Spring Constant } \\
\text { (kgf/mm) }\end{array}$ & 1,25 & 2,50 & 3,54 \\
\hline $\begin{array}{c}\text { Beban Awal } \\
\text { (kgf) }\end{array}$ & 10 & 0 & -28 \\
\hline $\begin{array}{c}\text { Beban Akhir } \\
\text { (kgf) }\end{array}$ & 47,5 & 75 & 77,88 \\
\hline
\end{tabular}

- SWR 31-80, beban awal dan akhir tidak terlalu keras.

- SWS 31-80, beban akhir terlalu keras.

- SWN 31-80, tidak ada beban awal dan spring longgar (oblag).

Perbandingan di atas bisa disimpulkan bahwa spring yang direkomendasikan untuk return pin dengan diameter 25 dan stroke 30 $\mathrm{mm}$ adalah SWR 31-80 yang beban awal dan akhir tidak terlalu keras. d. Hasil Perhitungan Screw Core Stop Block Hasil perhitungan ini bertujuan untuk mengetahui diameter yang diijinkan pada sebuah baut core stop block, adapun jumlah total baut yaitu 8 buah baut dan menggunakan material screw SCM435 dengan hasil diameter 6,43 untuk lebih amannya dipilih diameter diatasnya yaitu M8.

e. Hasil Perhitungan Eye Bolt

Eye bolt ini berfungsi untuk menahan berat mold saat proses pemindahan atau pergantian mold pada mesin injeksi, Maka dihitunglah diameter ijin baut pada eye bolt. Diameter yang diijiinkan 20,14 dengan menggunakan material SS400, tetapi untuk lebih amannya dipilih diameter M24.

\section{Proses Kerja Slider Mold}

Proses kerja sistem slider mold ketika awal injeksi sampai menjadi produk preform stick T15 akan dijelaskan pada langkah-langkah berikut ini.

\section{a. Molding Close}

Cetakan tertutup inilah proses pengisian dan pendinginan material yang telah membentuk produk preform stick T15, sehingga pada proses ini tidak ada plate yang terbuka. Gambar 20 dan 21, menunjukkan molding close.

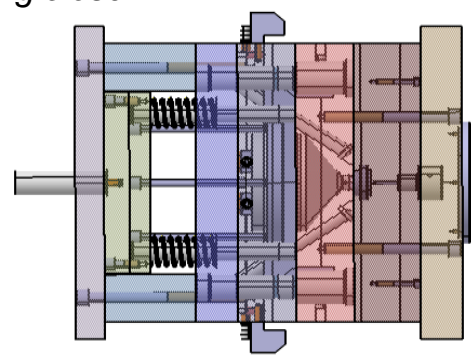

Gambar 20. Molding close (horizontal)

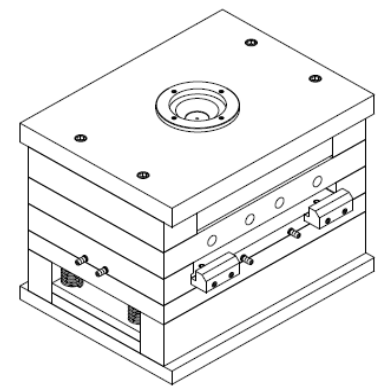

Gambar 21. Molding close (Isometric 2D) 


\section{b. Molding Open (1/2)}

Proses kerja molding (1/2) dengan sistem slider ini jika dilihat pada posisi vertical (gambar 22), tahap pertama posisi clamping unit menarik bagian bottom clamping plate ke arah -Z. Proses kerja dari slider sendiri ini saat membuka mold dengan bukaan bebas $72 \mathrm{~mm}$ di pandu dengan kemiringan angular pin yang sudah dipasang tetap pada bagian cavity plate, ditunjukkan pada gambar 23.

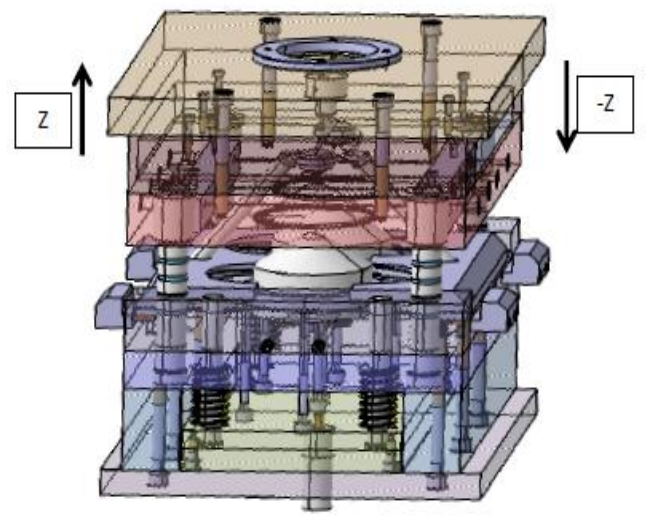

Gambar 22. Molding open 1/2 (vertical)

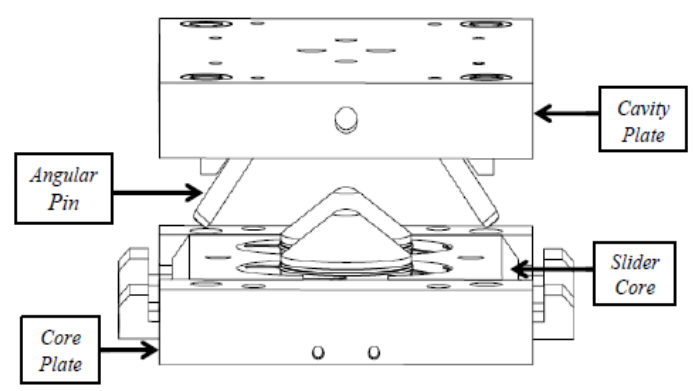

Gambar 23. Molding open 1/2 (Isometric 2D)

\section{c. Molding Open Full (Slider)}

Proses bukaan full cetakan yaitu clamping unit menarik bottom clamping plate kearah $-\mathrm{Z}$ yang mengakibatkan plate core, insert core, slider core, dan cavity terbuka, serta berhenti ketika sudah diatur oleh sistem kontrol pada mesin injeksi. Bukaan cetakan full ini, slider akan membuka dengan mengikuti kemiringan dari angular pin $37^{\circ}$ sebagai pemandu untuk membuka sebuah ulir yang ada pada produk preform stick T15, ditunjukkan pada gambar 23 dan 24.

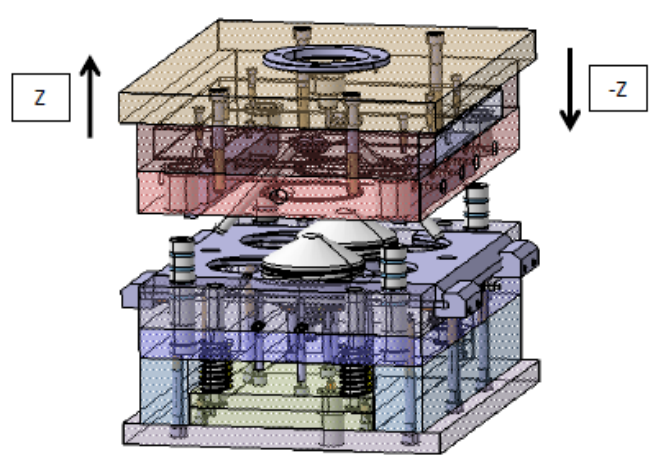

Gambar 23. Molding open full slider (Vertical)

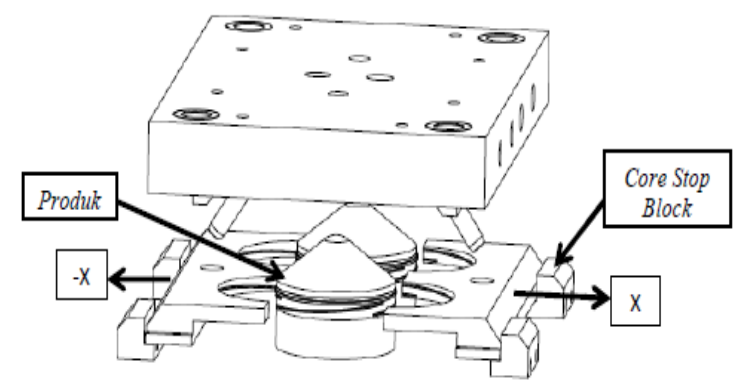

Gambar 24. Molding open full slider (Isometric 2D)

\section{d. Molding Open dan Ejection Produk}

Pada tahap pengeluaran produk (ejection produk) ketika dilihat dengan posisi vertical dengan satu unit stripper plate proses kerjanya yaitu dengan mendorong produk preform stick T15 dengan arah Z, akibat gaya dorong dari knockout yang mendorong ejector back plate dan ejector plate secara otomatis mendorong produk preform keluar dari cetakan dengan kebutuhan stroke $30 \mathrm{~mm}$. Ditunjukkan pada gambar 25 dan 26.

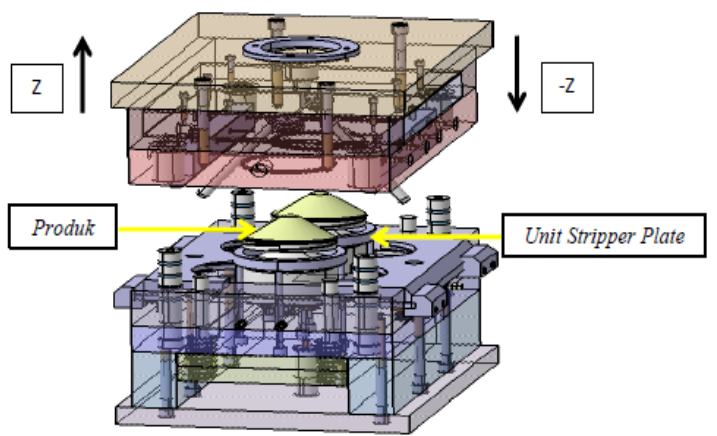

Gambar 25. Molding open dan ejection produk (vertical) 


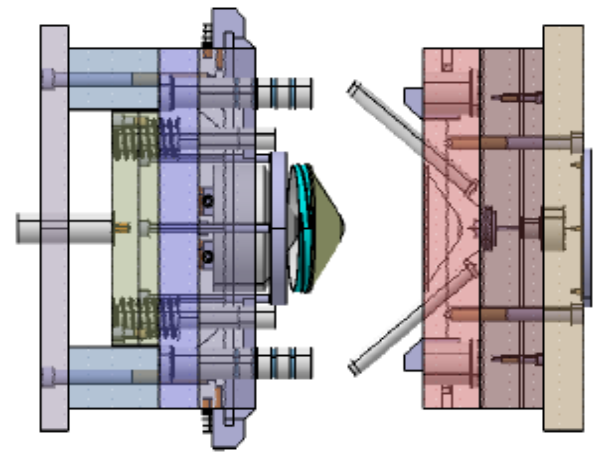

Gambar 26. Molding open dan ejection produk (horizontal)

\section{Locking Block}

Tahap terakhir setelah pengeluaran produk, proses selanjutnya yaitu cetakan menutup (molding close). Ketika cetakan bergerak menutup dengan dorongan dari clamping unit maka dari angular pin dengan kemiringan $37^{\circ}$ ini akan memandu lubang yang sudah ada dibagian slider core, kemudian pada kemiringan bagian locking block dengan kemiringan $39^{\circ}$ bertatapan pada bagian slider, dengan bertujuan untuk menahan slide core (slider) yang didorong tidak mundur saat tekanan injeksi. Dilihat pada gambar 27 dan 28.

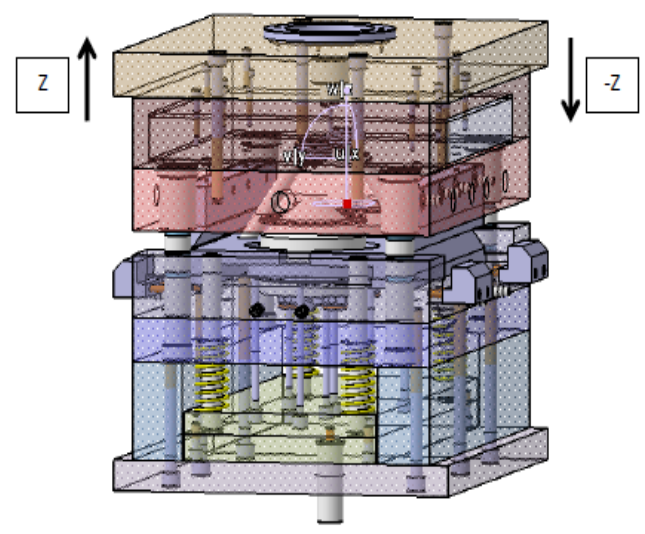

Gambar 27. Locking block (vertical)

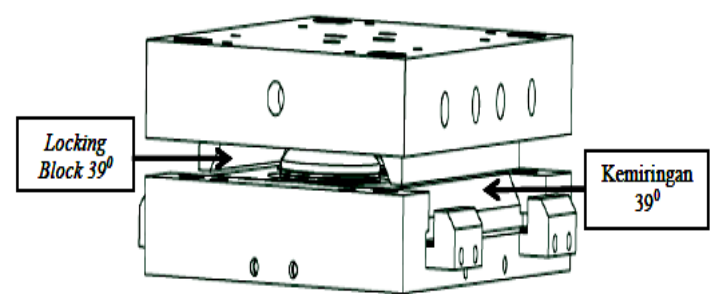

Gambar 28. Locking block (Isometric 2D)

\section{Kebutuhan Mesin}

Tabel 6, menunjukkan kebutuhan mesin cetakan injeksi yang akan digunakan saat proses pembuatan produk preform stick T15.

Tabel 6. Data kebutuhan mesin injeksi

\begin{tabular}{ll}
\hline \multicolumn{2}{c}{ Data Kebutuhan Mesin } \\
\hline Clamping force & $125 \mathrm{Ton}$ \\
\hline Opening stroke & $625 \mathrm{~mm}$ \\
\hline Mould height, fixed & $465 \mathrm{~mm}$ \\
\hline Platen daylight fixed & 700 \\
\hline Distance between tie bars & $450 \times 600$ \\
\hline Weight of movable mould half & $129,97 \mathrm{~kg}$ \\
\hline Ejector stroke & $30 \mathrm{~mm}$ \\
\hline
\end{tabular}

Kebutuhan mesin di atas, maka ditentukan mesin Arburg AllRounder 570S dengan maximum clamping force 160 Ton [7].

\section{KESIMPULAN}

Berdasarkan hasil perancangan Injection molding dengan sistem slider mold untuk produk preform stick T15, maka dapat diambil kesimpulan sebagai berikut:

1. Hasil analisa dan perbandingan pendinginan pada cetakan jenis cooling seri baffle type 1 dan cooling seri baffle type 2 , didapatkan analisa cooling type 1 dengan efisiensi penyerapan panas oleh cooling terhadap produk preform kurang cepat menyerap panas dan waktu yang dibutuhkan untuk mendinginkan produk sebelum proses ejeksi cukup lama. Sedangkan untuk cooling type 2 penyerapan panas dan waktu pendinginan produk lebih cepat dibandingkan cooling type 1. Sehingga di pilihlah cooling yang optimum dan terbaik yaitu cooling seri baffle type 2 merupakan pendingin cetakan yang direkomendasikan pada perancangan produk preform stick T15.

2. Hasil perhitungan slider, maka kemiringan angular pin yang berfungsi untuk memandu slide core ketika open dan close mold yaitu $37^{\circ}$ dengan panjang $120 \mathrm{~mm}$. Sedangkan kemiringan dari locking block harus lebih besar yaitu $39^{\circ}$ agar ketika bidang miring locking block dan slide core bersinggungan saat mold tertutup bisa mengalami gerakan yang lancar. 
3. Perhitungan tebal support plate, kekuatan ejector, push back spring, kekuatan screw core stop block, dan diameter ijin eye bolt pada perancangan slider mold dengan produk preform stick $\mathrm{T} 15$, dikatakan aman karena tegangan, gaya, dan penentuan material yang terjadi dibawah tegangan dan gaya ijin.

\section{DAFTAR PUSTAKA}

[1] Brydson, J.A. 1999. PLASTICS MATERIALS Seventh Edition. London: Butterworth Heinemann. halm, 170-171.

[2] Budiyantoro, Cahyo. 2009. Thermoplastik Dalam Industri. Surakarta: Teknika Media.

[3] Jones, Peter. 2008. The Mould Design Guide. United Kingdom: Smithers Rapra.
[4] Camaj, Michal. 2015. "Multy-cavity Injection Mold Design". Master Thesis, Faculty of Technology, Thomas Bata University in Zlin.

[5] Pindak, Martin. 2012. "Design of injection mold including cooling system optimization". Master Thesis, Faculty of Technology, Thomas Bata University in Zlin.

[6] Nakazawa, Makoto. 2010. Mold Basic Design Textbook. Jakarta: IMDIA..

[7] Goodship, Vannessa. 2004. Practical Guide to Injection Moulding. Germany: ARBURG Ltd. 